\title{
A BRIEF NOTE ON LEGAL PLURALISM AND COMPARATIVE LAW
}

\section{Paul Schiff Berman*}

At first blush, one might think that scholars of legal pluralism and those who study comparative law would be fellow travellers. After all, both groups of scholars are fundamentally focused on the multiplicity of legal systems in the world. Comparativists seek to catalog the components of various legal orders, either to demonstrate fundamental differences among those components or to reveal fundamental similarities. Meanwhile, legal pluralists study the inevitable interaction and overlap among legal and quasi-legal systems. Accordingly, legal pluralists and comparativists would seem to share a common analytical framework, based on the simultaneous existence of multiple legal orders.

Yet, the two scholarly fields have not always operated in concert. The divergence arises because comparative law scholars, like most legal scholars, have tended to study only official state-based municipal law, and they have often ignored the numerous other legal and quasi-legal orders that inevitably occupy the social field. These non-state normative systems are precisely the ones that legal pluralists insist we recognize and study. Accordingly, there has been a sometimes unspoken, but nevertheless real tension between the two bodies of scholarly literature. ${ }^{1}$

But is that tension inevitable? Is comparative law by definition tied to formal state-based municipal systems? To me, there seems no reason for that to be the case. It is true, of course, that it is often easier, as a practical matter, to pull apart components of municipal systems for study. After all, such systems tend to have codified and written down their substantive and procedural rules, as well as the outcomes of individual cases. Thus, the materials are far more easily accessible on electronic databases and through official newspaper accounts.

It is not at all clear, however, that there is any conceptual reason to limit comparative law study to official municipal law. All that is required for comparative law scholars to ply their trade is for there to be some form of institutionalized doctrine - to use Roger Cotterrell's helpful definition of law - as well as a group of human beings applying that doctrine. ${ }^{2}$ Neither of those parameters requires that the "law" in question be municipal law.

Consider three classic strands of comparative law scholarship. ${ }^{3}$ The first strand focuses on comparing and contrasting procedural and substantive norms. The second emphasizes migration and transplantation of procedural and substantive norms from one legal order to another. And the third aims to identify various structural, substantive, ideological and historical features that are common to "families" of legal systems. Taken together, these strands encompass most of what comparative law scholars do, and yet, again, none of these activities necessarily requires that the procedural and substantive norms or the institutional structures in question actually be formal municipal law.

\footnotetext{
George Washington University

Matthew Grellette \& Catherine Valcke, “Comparative Law and Legal Diversity - Theorizing About the Edges of Law.” Unpublished.

2 Roger Cotterrell, Law's Community: Legal Theory in Sociological Perspective (Oxford: Clarendon Press, 1995).

3 Ralf Michaels, "Comparative Law" in Basedow et al, eds, Max Planck Encyclopedia of European Private Law (Oxford: Oxford University Press, 2012).
} 
For example, take the recent book by Peer Zumbansen and Gralf-Peter Calliess. ${ }^{4}$ Though not framed as a comparative law study, at the core of the analysis is a discussion of the procedural participatory system constructed by the Internet Engineering Task Force [IETF], a non-governmental collection of computer engineers who together have helped to determine the underlying technological architecture of the Internet. As scholars have pointed out, this architecture is enormously important and tends to embed core policies (or laws) into the default rules of the system. ${ }^{5}$ Yet, there is no formal governmental entity controlling or supervising the IETF. Nevertheless, Zumbansen and Caliess study how this body both solicits opinions and achieves consensus in a remarkably open and inclusive way. Indeed, by some accounts the procedures of the IETF approach a Habermassian model for participatory decisionmaking. ${ }^{6}$ Regardless of whether or not one agrees with such accounts, however, it is clear that thinking about the IETF as a participatory legal system yields fruit regarding its distinctive structural features and the advantages and disadvantages of its choices. Indeed, to the extent comparativists tend to want to advocate legal transplants, certainly the procedural mechanisms or substantive norms of a non-state lawmaking body can inform a municipal legal system, or vice-versa.

Thus, there is no inherent structural impediment to comparative law scholars opening up their field of study to include non-state lawmaking of various forms. But can we go further? Is there an actual benefit to be gained from doing so? I believe there is. As the example of the IETF makes clear, such non-state lawmaking systems may be a source of examples of procedural or substantive norms that expand the possibilities of comparative analysis. Whether one sees comparative law only as a descriptive project or as one that uses comparative study to suggest advantageous legal transplants, having a broader range of sites of study seems to be an unalloyed good. After all, the more comparative sites, the more varieties of creative adaptation we might find.

Of course, one might hear the inevitable objection that we need a more defined boundary for what constitutes a legal system, lest comparative law scholars begin turning their lens to every normative custom, statement or decision in the world. But one need not engage in long and fruitless philosophical debates about what constitutes law to find a sufficient working definition (either Cotterrell's or someone else's) that would provide comparativists plenty of useful sites for study.

And not only can comparativsts benefit from an expanded comparative law lens, but so can legal pluralists. This is true, again, whether one conceptualizes the pluralist project as a descriptive or as a normative enterprise. Anthropologists and historians have often framed the study of legal pluralism in descriptive terms. Accordingly, they have catalogued the inevitable hybridity that arises when two legal or quasi-legal systems occupy the same social space, as well as the resulting strategic interactions that occur among actors in navigating the multiple regimes. More recently, scholars have advanced the idea that legal pluralism might be a normatively desirable approach to the design of legal systems by focusing on procedural mechanisms, institutions, and discursive practices that seek to manage

\footnotetext{
$4 \quad$ Peer Zumbansen \& Gralf-Peter Calliess Rough Consensus and Running Code: A Theory of Transnational Private Law (Oxford: Hart Publishing, 2010).

5 Lawrence Lessig, Code: And Other Laws of Cyberspace Version, 2.0 (New York: Basic Books, 2006).

6 A Michael Froomkin, “Habermas@Discourse.Net: Toward a Critical Theory of Cyberspace” (2003) 116 Harv L Rev 761.
} 
pluralism. $^{7}$ This proceduralist version of legal pluralism's normative project argues that the mechanisms, institutions, and practices that result may at times be preferable to procedural mechanisms that tend to choose one normative system to apply to a dispute, while eliminating others from the field.

Comparativists, because they are adept at spotting important structural features or underlying philosophical patterns of legal systems, should be of enormous help in the pluralist enterprise, either descriptive or normative. Comparativists could bring their analytical lens to a wide variety of non-state law-making institutions and catalog aspects of those normative systems. The result would be a richer body of literature seeking to understand the deep structure of these non-municipal law systems and a broader array of examples to be drawn upon by those seeking normatively to advocate the use of certain mechanisms over others.

In sum, the fields of comparative law and legal pluralism form a natural partnership. And if there is no reason other than historical happenstance for the comparative law focus on municipal law, then I think both groups of scholars should begin traversing the new terrain of non-state law in earnest.

$7 \quad$ Paul Schiff Berman, Global Legal Pluralism: A Jurisprudence of Law Beyond Borders (Cambridge: Cambridge University Press, 2012). 